http:/ / e-journal.stit-islamic-village.ac.id/index.php/JECIES

\title{
PERANAN ORANG TUA DALAM MEMBANTU PERKEMBANGAN EMOSI POSITIF DAN PERILAKU SOSIAL ANAK
}

\author{
Amita Diananda \\ STIT Islamic Village Tangerang \\ Email: amitadiananda.stit@gmail.com
}

Received: 28 Juli, 2020.

Accepted: 26 Agustus, 2020.

Published: 30 September, 2020

\begin{abstract}
The family is the smallest unit in society, consisting of father, mother and child. The closest environment for children to interact is family. The role of parents in the family is very important. Parents are central and the main source of the formation of values beld by children. Parents have a big responsibility in helping the quality of their children achieve the development of emotional maturity and social behavior with strong character and clear orientation. Neglect or lack of parental attention in shaping children's emotions and social behavior will have a major effect on children's ability to control their emotions and adapt, even in giving positive colors, to their environment. Emotion and behavior are two components that exist in humans that cannot be separated from each other (intertwined) where emotions affect behavior, not the other way around. Someone who is able to control their emotions will be able to control their behavior. Controlled emotions will provide a healthy space for the mind to think clearly and structurally. Conversely, a person who cannot control his emotions will not be able to control his behavior because the space for a bealthy mind and a clear mind is closed. Therefore, in educating children to have good, positive and constructive behavior, what parents must first build is to build and form strong character in children by prioritizing the power of emotional control.
\end{abstract}

\section{Keyword: Te Role Of Parents, Children, Social Behavior}

\begin{abstract}
ABSTRAK
Keluarga merupakan unit terkecil dalam masyarakat, terdiri dari ayah, ibu dan anak. Lingkungan terdekat bagi anak dalam berinteraksi adalah keluarga. Peranan orang tua dalam keluarga sangatlah penting. Orang tua adalah sentral dan sumber utama pembentukan nilai-nilai yang dianut oleh anak. Orang tua memiliki tanggung jawab besar dalam membantu kualitas anakanaknya mencapai perkembangan kematangan emosi dan perilaku sosial dengan karakter yang kuat dan orientasi yang jelas. Pengabaian atau kurangnya perhatian orang tua dalam pembentukan emosi dan perilaku sosial anak akan berpengarub besar terhadap kemampuan anak dalam mengendalikan emosinya dan dalam beradaptasi, babkan dalam memberikan warna positif, dengan lingkungannya. Emosi dan perilaku adalah dua komponen yang ada pada diri manusia yang tidak dapat dipisabkan satu sama lainnya (intertwined) dimana emosi mempengarubi perilaku, bukan sebaliknya. Seseorang yang mampu mengendalikan emosinya, maka dia akan mampu mengendalikan perilakuya. Emosi yang terkendali akan memberikan ruang yang sehat kepada
\end{abstract}


akal untuk dapat berpikir secara jernih dan terstruktur. Sebaliknya, seseorang yang tidak dapat mengendalikan emosinya, maka dia juga tidak akan dapat mengendalikan perilakunya karena ruang untuk akal yang sehat dan pikiran yang jernih sudah tertutup. Oleh karena itu, dalam mendidik anak agar memiliki perilaku yang baik, positif dan konstruktif, maka yang pertama kali harus dibangun oleh orang tua adalah membangun dan membentuk. karakter yang kuat pada diri anak dengan mengedepankan kekuatan pengendalian emosi.

\section{Keywords : Peranan orang tua, Anak, Emosi, Perilaku sosial}

\section{PENDAHULUAN}

Menjadi orang tua dituntut untuk memiliki kematangan emosional dan beberapa keterampilan interpersonal karena hubungan antara orang tua dan anak sesungguhnya adalah merupakan ikatan biologis dan emosional yang mendalam yang tidak bisa dipisahkan satu sama lain. Ikatan yang mendalam ini tercipta karena secara biologis, dengan segala komponen hereditasnya, anak berasal dari orang tua, sehingga secara naluriah, dalam setiap interaksi yang terjadi di antara mereka, akan tercipta kasih sayang (afeksi dalam bentuk cinta dan rasa memiliki serta tanggung jawab untuk melindunginya), dan itu adalah fitrah yang diberikan oleh Tuhan kepada manusia.

Orang tua merasa bahwa anak adalah penerus dari keberlangsungan kehidupan dirinya. Agar keberlangsungan kehidupan itu dapat berjalan dengan baik, bahkan jauh lebih baik, maka orang tua berusaha menurunkan segala kecakapan, kemampuan, pengetahuan, dan pola-pola interaksi yang berkesesuaian dengan kearifan pandangan dan sikap baik terhadap sesama maupun lingkungan alam sekitarnya. Pendidikan menjadi hal yang utama. Dalam ilmu psikologi pendidikan, pendidikan tidak cukup hanya mengarah kepada pendidikan kognitif saja, tetapi juga pendidikan yang bersifat afektif dan psikomotorik. Dibutuhkan keseimbangan yang ideal antara ketiga faktor pendidikan tersebut agar seorang anak dapat bertahan dan mengembangkan kehidupannya secara optimal. Orang tua sendiri dituntut mempunyai kesatuan antara kata dan perilaku, sehingga dapat diperoleh gambaran mengenai orang tua sebagai pendidik yang baik, sebagai figur ideal yang patut dicontoh pikiran, perkataan dan perbuatannya, terutama dalam soal pengendalian emosi.

Emosi menjadi penting bagi anak karena dunia anak dipenuhi oleh emosi dan pengalaman-pengalaman yang bersifat emosional. Emosi memberi energi untuk berfikir dan bertingkah laku sehingga anak dapat menyesuaikan diri dengan lingkungnnya (Goleman, 1995; Saarni et al.1998). Emosi yang berkembang pada masa anak-anak di antaranya: bahagia, marah, takut, sedih, benci, cemas, malu, rasa bersalah, dan rasa bangga. 
Selanjutnya, dalam perkembangan pendidikan sosial, orang tua dapat dikatakan sebagai manajer bagi perilaku aktifitas anak-anaknya dalam memberikan pengawasan dan bimbingan pergaulan.

Etika-etika pergaulan dalam berinteraksi dengan anggota keluarga dan anggota masyarakat sekitar (interaksi sosial) secara umum yang ditanamkan dan dibiasakan kepada anak sejak kecil adalah sikap-sikap seperti sopan santun, ramah tamah, sikap peduli dengan orang lain dan dengan lingkungan (binatang, tumbuhan dan alam), merupakan hal yang sangat penting, dengan harapan bahwa anak tersebut setelah dewasa akan mengetahui bagaimana mereka harus memandang, memikirkan dan menyikapi secara arif dunia sosial mereka. Interaksi yang sehat dengan orang lain (ada rasa nyaman dan aman) membuat anak memiliki kepercayaan pada orang lain, sedang hubungan yang tidak sehat akan membuat anak curiga, hati hati, dan waspada. Namun dalam dunia yang serba kompleks saat ini, kepercayaan, khususnya kepada orang asing yang baru dikenal, harus tetap dibangun dengan kecermatan dan kehati-hatian.

Hubungan sosial anak yang dibangun dengan baik dan sehat diharapkan kelak kalau dewasa dapat menjadikan dirinya tampil di masyarakat dengan penampilan terbaik yang ada pada dirinya sebagai manusia normal, berakal, cerdas, seimbang dan bijaksana. Gilbert Highest menyatakan bahwa kebiasaan yang dimiliki anak-anak sebagian besar terbentuk oleh pendidikan keluarga. Sejak dari bangun tidur hingga ke saat akan tidur kembali, anak-anak menerima pengaruh dan pendidikan dari lingkungan keluarga (Gilbert Highest, 1961:78).

Dalam perkembangan sosial anak, anak tidak terlepas dari hubunganhubungan yang menimbulkan sensasi batin atau perasaan atau emosi sebagai sikap reaktif terhadap lingkungannya, yaitu berupa respon positif atau respon negatif berupa "kosakata emosional" seperti bahagia, sedih, senang, marah, terkejut, kecewa, mengeluh, cemburu, dan banyak lagi yang lainnya.

Teori Ethological Attacment yang ditulis oleh John Bowlby $(1951,1958)$ menggambarkan betapa pentingnya perkembangan hubungan emosional antara anak dengan orang tua. Anak membutuhkan orang lain (orang tua) untuk dapat bertahan hidup (survive). Melalui kedekatan dengan orang tua seorang anak dapat menangis, bermanja dengan orang tua, dan menunjukkan perasaannya dengan nyaman, dapat tersenyum, dan tidak berada dalam kondisi yang penuh tekanan. Kehadiran orang tua sangat dibutuhkan untuk menjembatani perasaaan-perasaan emosional tersebut, sehingga anak-anak merasa aman, nyaman dalam beraktifitas. Segala perilaku, ucapan, sikap yang dilakukan orang tua kepada anak dalam kehidupan sehari-hari menjadi cerminan dalam kehidupan anak dalam kehidupan selanjutnya.

Dalam membantu perkembangan emosi dan perilaku sosial anak, orang tua perlu menerapkan suatu hubungan timbal balik yang dikenal dengan 
sosialisasi timbal balik. Selama ini, bertahun-tahun, sosialisasi orang tua dan anak dipandang sebagai suatu proses satu arah. Anak-anak dianggap sebagai produk dari teknik sosialisasi yang diterapkan orang tua mereka. Akan tetapi, saat ini, seiring dengan perkembangan tehnologi, khususnya tehnologi komunikasi, terjadi perubahan paradigma dalam menyikapi interaksi sosial antara orang tua dan anak. Yang sebelumnya satu arah, sekarang sudah berubah menjadi hubungan yang bersifat timbal baik. Sosialisasi timbal balik dapat diartikan sebagai suatu hubungan sosial dengan proses dua arah. Anakanak bersosialisasi dengan orang tua dan secara kongruen dan simultan (congruenly and simultaneously) orang tua secara aktif juga bersosialisasi dengan anak-anak. Dengan model sosialisasi seperti ini, maka komunikasi orang tua dan anak lebih terbuka, sehingga segala persoalan yang terjadi pada anak yang melibatkan emosi, tata cara dan sikap dapat secara dini terdeteksi dan diarahkan penyelesaiannya secara positif, komunikatif dan terhormat.

Emosi dan perilaku sosial merupakan dua aspek yang berlainan tetapi dalam kenyataannya kedua aspek ini menjadi satu bagian yang tidak dapat dipisahkan satu sama lainnya. Emosi menghasilkan suatu perilaku, dan perilaku adalah ekspressi dari emosi. Emosi terkendali maka perilaku juga akan terkendali. Perilaku yang lepas kendali mencerminkan emosi yang tidak terkendali. Pada kesehariannya, saat anak berinteraksi dengan orang lain, selalu dilingkupi dengan perasaan, dan perasaannya ini akan mewarnai perilaku yang dimunculkannya. Sebagai contoh, saat anak sedih atau kecewa maka ekspresi yang dimunculkannya bisa beragam. Pertama, anak gelisah. Kedua, anak menangis. Ketiga, anak berteriak-teriak. Keempat, anak berteriak-teriak sambil menangis atau diiringi tangisan. Kelima, anak tidak menangis tetapi ekspresi wajahnya cemberut (tanda kesedihan). Keenam, anak menangis atau tidak menangis dan kemudian menyendiri atau menghindar atau menjauhi temantemannya atau siapa saja, dan banyak lagi ragam ekspresi lainnya. Begitu pula sebaliknya, di saat hatinya senang, anak akan tersenyum atau melompat-lompat riang, atau bernyanyi berdendang, atau ia kemudian menjadi dermawan dengan memberikan mainannya untuk dipakai temannya atau dimiliki temannya, dan lain sebagainya.

\section{METODE}

Penelitian ini merupakan penelitian Library Research, dengan menggunakan pendektan analisis. Sumber primer penelitian ini Abdullah Nashih Ulwan, Pendidikan Anak Dalam Islam, dan Eilzabet B. Hurlock, Psikologi Perkembangan: Suatu Pendekatan Sepanjang rentang Kebidupan, 


\section{HASIL DAN PEMBAHASAN}

\section{A. Emosi}

Manusia seringkali ingin terbebas dari perasaan menyakitkan seperti marah, dendam, cemburu, malu, rasa bersalah, dan sedih. Sebaliknya, manusia menginginkan hal-hal yang menyenangkan, menggembirakan, membuatnya semangat, mencintai dan dicintai. Kedua perasaan yang bertolak belakang itu lah yang disebut dengan emosi. Bayangkan bagaimana seandainya dalam hidup ini kita tidak memiliki emosi. Tentu kita tidak akan merasakan keindahan dan keajaiban musik, tidak akan merasakan keindahan dan keajaiban cinta. Kita tidak akan peduli dan sedih kehilangan seseorang yang mencintai kita, karena kita sendiri tidak memiliki perasaan cinta, emosi cinta. Kita tidak akan pernah ketawa karena kita tidak memiliki perasaan senang dan merasakan sesuatu itu lucu. Kita tidak akan pernah merasakan letupan semangat untuk mendapatkan atau menggapai sesuatu. Semuanya hambar. Kita bagaikan zombi, makhluk yang sesungguhnya mati (dari rasa) tetapi kenyataannya hidup. Kita akan terisolasi dari kehidupan sosial karena kita tidak memiliki rasa apapun, tidak ada senyum, tidak ada tangis, tidak ada rasa sakit atau sensasi sakit, tentu juga menjadi tidak ada rasa takut. Kita juga tidak mengetahui apa yang dirasakan orang lain. Kita tidak akan melakukan apapun jika kita tidak memiliki emosi karena kita tidak akan peduli.

Emosi berkembang untuk membantu seseorang untuk memenuhi tantangan hidup atau memenuhi hajad hidupnya. Emosi menyatukan masyarakat, memotivasi mereka untuk mencapai tujuan, dan membantu mereka membuat keputusan dan rencana (Nessi dan Ellswort, 2009).

Dari uraian di atas mengenai emosi, ada beberapa ahli yang kemudian mencoba untuk mendefinisikan pengertian emosi, sebagai berikut:

Carole Wade menyatakan bahwa emosi (emotion) adalah suatu perasan atau afeksi yang melibatkan suatu campuran antara gejolak. fisiologis (misalnya, denyut jantung yang cepat) dan perilaku yang tampak. (misalnya, senyuman atau ringisan).

Kamus Besar Bahasa Indonesia (KBBI) On-line mengartikan emosi sebagai: 1. Suatu luapan perasaan yang berkembang dan surut dalam waktu singkat; 2. Suatu keadaan dan reaksi psikologis dan fisiologis (seperti kegembiraan, kesedihan, keharuan, kecintaan, kemarahan, dan keberanian yang bersifat subjektif); 3 . Rasa keagamaan yang merupakan getaran jiwa yang menyebabkan manusia berlaku religius

Pada konteks psikologi, emosi diartikan sebagai gejala psikologis yang menimbulkan efek pada persepsi, sikap dan perilaku serta mewujud dalam bentuk ekspresi tertentu. Terminologi emosi yang kita gunakan sehari-hari sangat berbeda dengan pengertian psikologi. Emosi dalam pemakaian 
sehari hari hanya mengacu pada ketegangan yang terjadi pada individu sebagai akibat dari tingkat kemarahan yang tinggi. Sedangkan emosi dalam pengertian psikologi mencakup semua perasaan atau sensasi yang ada pada diri manusia.

Selain emosi dalam pengertian umum, terdapat juga istilah "Kecerdasan Emosi" (Emotional Intelligence) yang menurut Goleman adalah suatu kemampuan untuk mengenali perasaan kita sendiri dan perasaan orang lain, kemampuan memotivasi diri sendiri, dan kemampuan mengelola emosi dengan baik pada diri sendiri dan dalam hubungannya dengan orang lain.

Emosi, dan juga kecerdasan emosi, dimiliki dan memenuhi siapa saja, baik itu anak-anak, remaja, maupun orang dewasa. Emosi berkembang serentak bersamaan dengan perkembangan fisik, sosial, kognitif, dan bahasa. Perkembangan emosi memiliki peranan penting dalam perkembagan anak, baik pada usia pra sekolah maupun pada jenjang pendidikan selanjutnya. Anak mengkomunikasikan perkembangan emosinya melalui bahasa verbal, gerakan dan bahasa tubuh.

Para psikolog mengklasifikasikan emosi dengan banyak cara yang berbeda, tetapi dari semua klasifikasi yang ada, terdapat satu karakteristik yang disepakati bersama baik secara terang-terangan atau tidak, yaitu 'apakah emosi itu positif atau negatif' (Pennebaker, 1992), yang kemudian diistilahkan dengan kata "Afektifitas Positif' dan Afektifitas Negatif'.

Afektifitas Positif (Positive Affectivity, disingkat PA) mengacu kepada derajat emosi yang positif, dari energi yang tinggi, antuisme, dan kegembiraan hingga perasaan sabar, tenang, dan menarik diri. Sukacita, kegembiraan, dan tertawa termasuk perasaan yang positif.

Sedangkan Afektifitas Negatif (Negative Affectivity, disingkat $N A$ ) mengacu kepada emosi yang sifatnya negatif, seperti kecemasan, kemarahan, perasaan bersalah, dan kesedihan.

PA dan NA ini merupakan dimensi yang independen, dalam arti seorang anak dapat berada pada derajat yang sama tinggi pada kedua dimensi tersebut pada waktu yang sama. Misalnya, ia berada di dalam keadaan energi yang tinggi, bersemangat tinggi dan sekaligus dalam kondisi marah).

\section{B. Fungsi Emosi}

Setiap individu mempunyai karakteristik emosi yang berbeda beda, ada anak yang rewel, ada yang selalu ceria dan mudah diatur, ada yang penakut, ada yang pemberani dan menyukai hal-hal yang baru, ada yang pendiam dan pemalu, ada yang suka bergaul dan ada yang suka menyendiri. Hal itu menggambarkan sikap (attitude), keadaan hati (mood), tingkah laku (behavior) 
yang sifatnya umum (konstitusional) sebagai ujud dari reaksi emosional seseorang terhadap suatu peristiwa atau keadaan yang baru dialami (Kagan, 1998, Rothbart \& Bates, 1998).

Seiring dengan bertambahanya usia seorang anak, maka kemampuan untuk mengelola emosinya akan semakin baik. Emosi bisa mendatangkan keburukan jika individu tersebut tidak bisa mengendalikan emosinya dengan baik, dan bisa juga mendatangkan kebaikan ketika induvidu tersebut dapat mengolahnya dengan baik.

Emosi merupakan reaksi terhadap rangsangan dari luar dan dalam diri individu. Sebagai contoh emosi gembira dapat mendorong perubahan sikap seseorang yang secara fisiologi terlihat dalam bentuk tawa ceria. Sedangkan emosi sedih mendorong seseorang berperilaku sendu, bahkan sampai menangis. Emosi mempunyai tiga fungsi (Bretherton, dkk.,1986), yaitu:

1. Penyesuaian diri dan kelangsungan hidup (adaptation and survival).

Berkaitan dengan penyesuaian diri dan kelangsungan hidup, seorang anak dalam menghadapi ketakutan, misalnya, akan berusaha untuk menyesuaikan dirinya dengan hal yang ditakutinya itu (adaptation) sehingga dirinya tidak mengalami hal-hal yang bersifat buruk (survival).

2. Pengaturan (regulation).

Berkaitan dengan pengaturan, seorang anak yang sedang dalam keadaan gembira cenderung untuk lebih memperhatikan (mengikuti aturan) apa-apa yang sedang dikaji dan dipelajarinya dibandingkan dengan anak yang sedang mengalami kesedihan.

3. Komunikasi

Yang dimaksud dengan komunikasi disini adalah proses penggambaran emosi hati atau refleksi diri dari rasa yang ada dalam hatinya dalam bentuk perilaku-perilaku (communicating emotion or feeling in terms of attitude or behavior). Misalnya, seorang anak yang merasa bersalah akan memperlihatkan tingkah laku yang kikuk, atau seorang anak yang sedang membenci sesuatu akan menampakkan raut muka yang tidak menyenangkan (ketidaksukaan terhadap sesuatu).

Ada pendapat dari beberapa ahli tentang bagaimana mengembangkan emosi secara praktis, yaitu pendapat dari:

1. Agus-Steiner

Cara untuk mengembangan kecerdasan emosi menurut Agus-Steiner adalah dengan melakukan langkah-langkah sebagai berikut (terdapat 3 langkah):

a. Membuka hati

Hati adalah simbul pusat emosi karena hanya hati yang bisa merasakan kebahagiaan, kasih sayang, cinta, sakit (hati), sedih, marah atau perasaan-perasaan lainnya. Oleh karena itu orang tua 
harus bisa membuka hatinya sendiri, artinya ia harus mampu membebaskan dirinya dari sikap-sikap yang bersifat sesaat (impulsive), tidak terus menerus, dan sikap-sikap yang menghalangi dirinya untuk menunjukkan cintanya kepada anaknya. Dalam hal ini tahapan untuk membuka hati adalah dengan memberikan sentuhan yang lembut kepada anak, meminta sentuhan, menerima atau menolak sentuhan. Orang tua harus bisa mengesampingkan egonya. Orang tua jangan terlalu memaksakan kehendaknya kepada anak, tetapi selami dan pahami apa yang dirasakan anak dan bagaimana karakternya. Sekalipun perilaku anak itu kadangkadang menjengkelkan, orang tua perlu belajar ikhlas, berlapang hati, dan selalu membuka ruang maaf untuk anak-anaknya.

b. Menjelajah emosi

Yang dimaksud dengan menjelajahi emosi disini adalah suatu upaya yang terus menerus dilakukan untuk mempelajari dan memahani emosi seseorang (anak). Emosi dapat dipicu oleh berbagai macam sebab. Peristiwa yang sederhana bisa memunculkan emosi yang tinggi apabila hatinya sedang tidak dalam keadaan baik (tidak mood), sebaliknya peristiwa yang menjengkelkan tidak akan memunculkan emosi yang berlebihan apabila hati sedang dalam keadaan bahagia. Kemampuan untuk dapat memahami keadaan emosi orang lain itu penting sehingga dalam berinteraksi kita menjadi lebih bijak dalam mengelola perasaan kita sendiri dan sekaligus menyikapi perasaan orang lain. Orang tua dalam menjelajahi emosi anak-anaknya terkadang butuh waktu. Misalnya, anak sedang sedih, maka apabila anak menginginkannya, orang tua dapat meninggalkan anak itu sendirian untuk mengatasi kesedihannya, atau berbicara pelan dan lembut kepadanya dengan memperlihatkan simpati dan/atau empati terhadap persoalan atau hal yang menyebabkannya sedih, serta memberikan dukungan dan saran bagaimana harus mengatasi kesedihan dan persoalan yang membuatnya sedih itu.

Tahapan menjelajahi emosi ini meliputi pernyataan-pernyataan atau tindakan atau ungkapan perasaan, menerima pernyataan atau perasaan, mengecek kemungkinan-kemungkinan (atau asumsiasumsi, atau kadangkala disebut sebagai percikan intuisi) penyebab dari munculnya emosi anak, dan kemudian menguji asumsi-asumsi tersebut (validasi percikan intuisi).

c. Bertangung jawab

Sikap tanggungjawab merupakan sikap yang terpuji. Dalam berhubungan dengan orang lain kadang ada perbedaan persepsi 
sehingga kadang ada kesalahpahaman. untuk memperbaiki dan mengubah kerusakan hubungan antara anak dengan anak lain atau dengan siapapun, orang tua kadangkala harus bertindak arif mengambil tanggung jawab agar masalah cepat teratasi. Setiap orang tua harus mengerti permasalahan, mengakui kesalahan dan keteledoran yang terjadi, membuat perbaikan, dan memutuskan bagaimana mengubah segala sesuatunya (menjadi lebih baik), dan kemudian melakukan perubahan itu sendiri. Dengan demikian, langkah-langkah untuk menjadi bertanggung jawab adalah dengan mengakui kesalahan, menerima atau menolak pengakauan, meminta maaf, dan menerima atau menolak permohonan maaf (apabila tidak ditemukan adanya kesalahan).

2. Gaya Agus-Gottmann

Modifikasi Gaya Agus-Gottmann sangat praktis terutama untuk membina kerjasama dan saling pengertian baik dengan teman, siswa, anak-anak, orang tua dan lain lain. Terdapat 6 (enam) langkah pengembangan emosi menurut Agus-Gottman yaitu:

a. Menyadari Emosi Anak

Orang tua dalam menghadapi emosi anak harus merasakan juga apa yang dirasakan mereka atau mengalami empati, tanpa bersikap sangat ekspresif dan tanpa merasa seolah-olah mereka kehilangan kendali sehingga orang tua siap sebagai pelatih emosi. Dibutuhkan kepekaan orang tua dalam mengenal emosi anak walaupun tidak gampang memahami perasaan-perasaan mereka. Anak-anak mempunyai alasan bagi emosi mereka, entah mereka dapat mengungkap alasan itu atau tidak. Orang tua harus mengetahui atau mengenali gejalanya saat anak sedang dalam keadaan emosional dan menggunakannya sebagai kesempatan untuk menjalin kepercayaan saling memberi.

b. Mengakui Emosi Sebagai Kesempatan

Persoalan emosi yang dialami anak seperti nilai pelajaran yang buruk, pengkhianatan seorang teman atau pengalaman-pengalaman negatif lainnya semacam itu dapat berguna sebagai peluang bagi orang tua untuk berempati, untuk membangun kedekatan dengan anak, dan membantu mereka cara-cara untuk menangani atau mengatasi perasaan mereka itu.

c. Mendengarkan dengan empati

Setelah orang tua mampu melihat situasinya dan melihatnya sebagai suatu kesempatan untuk menjalin keakraban dan membantu memecahkan masalah, maka sikap atau tindakan yang perlu dilakukan selanjutnya adalah dengan mendengarkan sepenuh hati 
dan perhatian serta serius merespon hal-hal yang menjadi keprihatinan anak serta bersedia meluangkan waktu untuk berdiskusi dalam menyelesaikan masalah tersebut.

d. Mengungkapkan nama emosi

Salah satu langkah dalam pelatihan emosi adalah menolong memberi nama emosi mereka sewaktu emosi itu mereka alami. Semakin tepat seorang anak dapat mengungkapkan perasaan mereka dengan kata-kata, maka hal itu semakin baik. Apabila anak sedang marah atau sedih, maka anak didorong untuk bisa mengungkapkan dengan kata-kata penyebab kemarahan atau kesedihannya itu, misalnya dengan mengatakan kecewa, bingung, dikhianati, cemburu, sakit hati ditinggalkan sahabat, iri pada teman, hampa di tengah keramaian, dan lain sebagainya.

e. Membantu menemukan solusi

Setelah kita membantu anak memahami dan menemukan emosinya, kemudian kita menuju dalam suatu proses pemecahan masalah. Proses pemecahan masalah ini memiliki 5 (lima) tahap yaitu:

1) Menentukan batas-batas masalah

2) Menentukan sasaran kepada lingkungan

3) Memiliki pemecahan yang mungkin

4) Mengevaluasi pemecahan yang disarankan berdasarkan nilainilai keluarga

5) Menolong anak memilih satu pemecahan

6) Jadilah teladan

Menurut kaca mata Quantum Teaching, keteladanan adalah tindakan yang paling ampuh dan efektif yang dapat dilakukan oleh seorang pelatih emosi atau orang tua. Keteladanan dapat mempengaruhi perilaku dan tindakan tanpa banyak kata-kata. Orang tua yang berkomitmen menjadi teladan bagi anak-anaknya. Kecerdasan emosi akan memancarkan radiasi emosi positif kepada lingkungan dan memudahkan bagi anak-anak untuk meningkatkan kecerdasan emosi. Perkembangan emosi anak berbeda-beda seiring dengan bertambahnya usia anak, hal ini karena sejalan dengan kedewasaannya, lingkungan, reaksi orang di sekitarnya, atau pola asuh orang tua. Dalam mengelola emosi, anak prasekolah berbeda dengan anak yang sudah masuk Sekolah Dasar (SD), Sekolah Menengah Pertama (SMP), dan Sekolah Menengah Atas (SMA). Masing masing mempunyai ciri khas tersendiri. Perkembangan emosi memang memiliki dasar fisik dan kognitif bagi perkembangan anak, tetapi begitu kemampuan dasar terbentuk, emosi lebih situasional atau terkontrol. 


\section{Mengatasi emosi}

Pada hakekatnya, setiap orang mempunyai emosi, dari bangun tidur pagi hari sampai waktu tidur malam hari, begitu pun juga anak-anak akan mengalami pengalaman yang menimbulkan berbagai emosi. Misalnya, pada saat makan pagi bersama keluarga, anak merasa gembira, tetapi kemudian menjadi sebaliknya. Boleh jadi di waktu yang sama ketika anak menuju ke sekolah ternyata jalanan macet sehingga terlambat datang ke sekolah. Ketika terlambat ke sekolah anak kena hukuman yang mengakibatkan anak merasa malu dengan teman-temannya dan guru. Atau bisa jadi ada kejadiankejadian di sekolah yang membuat anak sedih karena diejek oleh teman atau dipukul teman dan kejadian-kejadian lainnya.

Kehadiran orang tua dalam membantu situasi emosional yang tidak sesuai adalah dengan cara:

1. Singkirkan atau kurangi penyebab emosi, misalnya dengan pelukan, menenangkan dengan kata-kata yang menyejukkan, atau dengan mengajak pergi ke luar rumah dan sebagainya.

2. Redakan respon negatif dengan membiarkannya "mengeluarkannya" melalui tangisan, bicara, atau memindahkan perasaaanya ke tindakan non-destruktif.

3. Tawarkan dukungan, kenyamanan, dan ide untuk kontrol diri.

4. Beri anak kesempatan untuk membicarakan perasaaan negatif secara sesuai.

\section{Definisi Sosial dan Perilaku Sosial}

Tim Pustaka Phonix, dalam Kamus Besar Bahasa Indonesia, mengartikan kata sosial sebagai segala sesuatu mengenai masyarakat, atau kemasyarakataan, atau suka memperhatikan kepentingan umum, atau suka menolong, menderma dan sebagainya. Sedang kesosialan diartikan sebagai sifat-sifat kemasyarakatan.

Arti yang sama diberikan oleh Hasan Alwi, dkk., dalam Kamus Besar Bahasa Indonesia, dimana Sosial dimaknai sebagai suatu sikap yang suka memperhatikan kepentingan umum, seperti suka menolong, menderma, dan sebagainya.

Menurut Lead ada tiga kriteria yang menentukan perilaku suka menolong (altrustic), yaitu:

1. Tindakan yang bertujuan khusus menguntungkan orang lain taanpa mengharapkan hadiah;

2. Tindakan yang dilakukan secara sukarela;

3. Tindakan yang menghasilkan sesuatu yang baik;

Perilaku sosial adalah aspek positif perkembangan moral. Wilayah ini mencakup perilaku empati, kemurahan hati, kerjasama, kepedulian. 
Empati adalah suatu kondisi dimana anak-anak mengekspresikan kasih sayang dengan menghibur atau menyenangkan seseorang dalam kesusahan atau dengan mengungkapkan perasaan anak lain selama konflik interpersonal; Kemurahan hati adalah kondisi dimana anak-anak berbagi atau memberikan miliknya kepada seseorang;

Kerjasama adalah kondisi dimana anak-anak bergiliran secara sukarela atau memenuhi permintaan dengan riang gembira; dan Kepedulian adalah kondisi dimana anak-anak membantu seseorang menyelesaikan tugas atau membantu seseorang yang membutuhkan pertolongan/bantuan.

Perilaku pro-sosial yang dilakukan anak karena anak menyerap semua yang terjadi di sekitar mereka. Apa yang dilakukan orang tua pada anak di masa kecil bisa menjadi pengalaman sendiri bagi emosi anak. Misalnya, pada saat anak membutuhkan sesuatu, orang tua selalu memperhatikannya, atau pada saat anak kecewa dengan sesuatu hal, orang tua kemudian segera menghiburnya. Juga hal-hal yang dilakukan orang tua saat tidak sepakat dengan anak tentang sesuatu hal akan menjadi pengalaman tersendiri bagi anak, dan lain sebagainya. Setiap situasi emosional menghadirkan pola perilaku kuat yang bisa ditiru oleh anak. Termasuk perilaku antisosial dimana perilaku ini menyimpang dari norma-norma, baik aturan keluarga, sekolah, masyarakat maupun hukum. Perilaku anti sosial ini dibagi dua jenis. Pertama, perilaku sosial yang tampak (overt), misalnya perilaku agresif. Kedua, perilaku yang tak tampak (covert) yang non-agresif yang berupa pelanggaran terhadap aturan dengan sikap berbohong.

Area utama dari perkembangan hubungan sosial adalah pertemanan. Dalam pertemanan, anak ingin bisa bermain sebanyak mungkin dengan teman-temannya terutama dengan teman yang sebaya. Anak juga mulai memahami bahwa fungsi pertemanan adalah untuk berbagi, memberi dukungan, dan bergantian. Dalam pertemanan, anak juga akan mendapatkan pengalaman sosial. Semenjak usia dini, pengalaman sosial tersebut kelak akan memainkan peranan yang penting dalam menyatukan hubungan sosial anak.

\section{E. Mengembangkan Perilaku Prososial Anak}

Pengalaman sosial yang dimiliki oleh anak dapat dilihat dari respon yang dimilikinya dalam pertemanan. Sejak awal kehidupan bayi, respon terhadap perilaku dan kehadiran bayi lain yang sebaya sudah muncul. Pada usia 2 bulan bayi sudah mengamati bayi lain seusianya. Pada usia 3-4 bulan dia akan menyentuh bayi lainnya sebagai upaya mencari dan mengharapkan respon sosial dari bayi yang lain. Perkembangan sosial ini akan terus berkembang mengalami kemajuan hubungan sosial sampai usia anak menginjak dewasa. 
Perilaku sosial merupakan kegiatan yang berhubungan dengan orang lain, kegiatan yang berkaitan dengan pihak lain yang memerlukan sosialisasi dalam hal berperilaku yang dapat diterima orng lain, belajar memainkan peran yang dapat diterima orang lain, serta upaya mengembangkan sikap sosial yang layak diterima orang lain.

Banyak hal yang bisa dilakukan orang tua dalam perilaku kehidupan sosial anak yaitu:

1. Mengatasi Konflik

Konflik selalu terjadi dalam kehidupan berinteraksi dengan lingkungan. Apabila anak menemui konflik dengan temannya, orang tua memberikan kesempatan dalam mengatasi berbagai konflik pertemanan yang dialami anak dengan menanyakan bagaimana perasaan anak kalau tersakiti atau perasaan teman yang tersakiti oleh anak kita sehingga anak bisa saling menyadari perasaan satu sama lain. Konflik juga bisa terjadi antar orang tua dan anak karena perbedaan persepsi, keinginan, batasan-batasan nilai-nilai yang orang tua terapkan. Konflik seperti itu wajar selama segera terselesaikan dengan baik. Jangan sampai konflik orang tua dan anak memicu tumbuhnya rasa antipati, benci, dan bahkan dendam.

2. Kedermawanan

Para peneliti menemukan bahwa anak yang lebih tua lebih mungkin untuk berbagi daripada yang lebih muda. Berbagi dengan teman sebaya, ternyata meningkat secara dramastis antara usia 4 dan 12 tahun. Orang tua memberikan contoh bagaimana berbagi dengan sesama anggota keluarga ataupun dengan orang lain. Di sekolah pun anak anak juga bisa belajar berbagi dengan teman-temannya. Dengan bertambahnya usia dan bertambah kematangan secaraa kognitif, anakanak akan kurang peduli dengan diri mereka sendiri sebagai pusat segala sesuatu dan lebih peduli dengan orang lain.Kebiasan memberi harus terus ditumbuhkan di dalam keluarga.

3. Kerja sama

Kerja sama mencakup berbagai perilaku prososial, termasuk bergiliran; bergantian menggunakan mainan; peralatan; atau kegiatan; memenuhi permintaan; mengkoordinasikan tindakan-tindakan untuk mencapai tujuan ; menerima ide-ide anak-anak lain, dan bernegosiasi dan berkompromi dalam bermain.

4. Kepedulian

Untuk menumbuhkan sifat kepedulian anak, orang tua selalu melibatkan anak dalam situasi yang membutuhkan pertolongan yang mungkin terjadi di dalam rumah atau di luar rumah misalnya rumah tetangga, sebagai contoh peristiwa ada seseorang yang terjatuh dan 
kesakitan, ada yang teriris pisau, atau terbakar api, kehilangan sesuatu misalnya kehilangan uang, barang, atau mainan dan lain sebagainya anak terlibat membantu untuk mengatasi hal tersebut. Orang tua juga memberikan contoh bagaimana menghibur orang yang sedang kesusahan dengan memberikan bantuan materi, memberi nasehat dengan motivasi, atau menyampaikan informasi-informasi yang dibutuhkan sehingga anak dapat belajar dari perilaku orang tuanya. Di dalam rumah, anak juga dilibatkan dalam membereskan barang-barang yang tumpah, mencari barang yang hilang, atau memberikan informasi untuk membantu orang dewasa menyelesaikan masalah. Di harapkan dengan kebiasaan -kebiasan ini di pupuk setiap hari maka anak akan merasa bahwa dirinya dibutuhkan orang lain dan dirinya membutuhkan oranglain dalam berinteraksi. Perilaku sosial juga bisa diajarkan pada saat anak-anak saat anak melihat langsung siaran di televisi tentang bencana alam, misalnya banjir, kekeringan, ditindas oleh orang atau bangsa lain dengan memberi bantuan kepada mereka.

5. Perhatian

Anak-anak tumbuh dan berkembang melalui tahun-tahun anakanak usia dini sampai anak remaja. Anak dibiasakan dilibatkan untuk lebih perhatian untuk mencoba dan merasakan membantu tugas-tugas dalam rumah misalnya membantu menyediakan makan pagi, membersihkan rumah, mengeluarkan ranjang lipat atau matras untuk tidur siang, memberi makan hewan piaraan dan lain sebagainya. Berilah tugas tugas rumah sesuai dengan usia kematangan dan jangan terlalu membebaninya. Itulah cara-cara terbaik anak untuk lebih bisa memahami lingkungan sekitar.

\section{F. Problematika Perkembangan Emosi dan Perilaku Pro-Sosial Anak}

Aspek emosi dan prososial pada anak perkembangannya dapat dilihat manakala anak bertemu dan berinteraksi dengan seseorang. Demikian juga dengan berbagai masalah perkembangan emosi -sosial pada anak yang mudah sekali ditemukan dalam kehidupan keseharian kita. Masalahmnasalah tersebut antara lain:

1. Penakut

Penakut berasal dari kata takut yang berarti merasa gentar (ngeri) menghadapi sesuatu yang dianggap akan mendatangkan bencana ataupun bahaya. Sedangkat penakut berarti orang yang takut, mudah takut, tampak takut, dan menjadi takut. lawan ddari takut adalah 
pemberani.Rasa takut ini tidak hanya dialami anak-anak tetapi juga pada orang dewasa.

Abdullah Nashih Ulwan menjelaskan bahwa padsa anak usia 3 tahun mulai banyak sekali hal-hal yang ditakuti oleh anak, seperti takut pada halilintar, binatang, keadaan gelap, dn lainnya. Secara umum anak perempuan lebih banyak menampakkan ketakutannya jika dibandingkan dengan anak laki-laki dan rasa ketakutannya pun akan berbeda sesuai dengan kondisi dan imaginasi anak. Jika intensitas imaginasinya lebih banyak, maka ras ketakutannya akan lebih banyak pula.

Novita Tandry merinci perkembangan rasa takut pada anak sebagai berikut :

Tabel 1. Perkembangan rasa takut pada anak

\begin{tabular}{llll}
\hline No & Usia & Obyek yang ditakuti \\
\hline 1. & $\begin{array}{l}\text { Setelah baru } \\
\text { lahir }\end{array}$ & Suara nyaring/ keras \\
\hline 2. & 6 bulan - 3 tahun & Orang asing \\
\hline 3. & $\begin{array}{l}9 \text { bulan } \\
\text { tahun }\end{array}$ & Tempat-tempat tinggi \\
\hline 4. & $2-4$ tahun & Binatang & \\
\hline 5. & $4-6$ tahun & $\begin{array}{l}\text { Kegelapan, badai, } \\
\text { khayalan }\end{array}$ \\
\hline 6. & $6-12$ tahun & \begin{tabular}{l} 
Hal-hal yang misterius yang terjadi \\
\hline 7.
\end{tabular} $12-18$ tahun & $\begin{array}{l}\text { Rasa malu secara sosial, kegagalan } \\
\text { akademis, kematian, dan perang }\end{array}$ \\
\hline
\end{tabular}

Setiap anak tentunya memiliki rasa takut, tetapi ada rasa taakut yang wajar serta ada pula yang berlebih sehingga menimbulkan masalah sosial emosi pada anak. Jika rasa takut berlebihan maka dapat mengganggu kesehatan, kemudian kegiatan dan perilaku kesehariannya pun semakinmenurun kualitasnya.

2. Pencemas

Pencemas berasal dari kata cemas yang berarti tidak tentram hati, khawatir, dan gelisah. Sedangkan pencemas adalah orang yang mudah cemas.

Perasaan cemas cukup sering menganggu anak. Dalam jumlah tertentu, kecemassan merupakan hal yang normal. Kecemassan baru menjadi masalah manakala kecemasan pada anak telah mencapai tingkat yang intens yang dapat menganggu kemampuannya dalam melaksanakan tugas-tugas kesehariaannya. Novita Tandry 
mengungkapkan bahwa kecemasan dialami secara fisik dan berhubungan dengan rangsangan fisiologis yang tinggi yang dapat menjadikan kecemasan dapat menyebabkan gejala berikut ini:
a) Gugup dan detak jantung semakin cepat
b) Berkeringat
c) Tekanan pada otot dan rasa ssakit pada otot
d) Bergetar daan kehilangan koordinasi
e) Mulut kering dan pandangan mata kabur
f) Kepala pusing dn pingsan
g) Kurang konsentrasi
h) Perut kejang dan massalah pernafassan
i) Sering ke toilet
j) Selera makan dan tidur terganggu.

3. Rendah Diri

Sinonim dari rendah diri adalah minder. Secara sederhana rendah diri dapat diartikan sebagai suatu perasaan yang menjadikan anak merasa kurang mampu (kompeten) jika bandingkan dengan anak yang lainnya.

Setidaknya ada 9 (sembilan) hal yang dapat menyebabkan anak dilingkupi perasaan rendah diri, antara lain:

a) Orang tua mendidik anak dengan cara yang keliru dan berdasarkan ancaman, kekerasan, serta pemukulan setiap kali anak berbuat kesalahan atau bermain sesuatu yang dapat membahayakan atau yang tidak disukai orang tua.

b) Orang tua selalu membatasi setiap perilaku anak dan juga cara berfikirnya.

c) Orang tua selalu membandingkan anak dengan anak lainnya meskipun. sebenarnya tujuaanya adalah memotivasinya karena haal itu justru dapat pengaruh yang sebaliknya.

d) Orang tua meremehkan kemampuan dan harga diri anak serta melemahkan minatnya

e) Anak memiliki bentuk badan kecil dan memiliki cacat tubuh.

f) Rendahnya IQ dan memiliki keterlambataan dalam belajar.

g) Orang tua mudah mencela anak di saat ia mengalami kegagalan saat melakukan sesuatu.

h) Banyaknya pertengkaran antara kedua orang tua.

\section{SIMPULAN}

Emosi adalah bagian yang sangat penting dalam diri manusia karena dengan adanya emosi seorang manusia dapat merasakan berbagai macam perasaan, seperti rasa bahagia, rasa cinta, rasa kasih sayang, rasa aman, rasa

JECIES: Journal of Early Childhood Islamic Education Study 
nyaman, semangat, kemauan, rasa puas, sedih, kecewa, khawatir, takut, cemas, rendah diri, dan lain sebagainya. Tanpa adanya emosi maka kehidupan seseorang tidak ubahnya dengan makhluk yang tak bernyawa seperti tumbuh tumbuhan, batu, tanah dan lain sebagainya.

Mengingat bahwa tingkah laku manusia adalah merupakan refleksi dari emosi seseorang, maka diperlukan kearifan dalam mengelola emosi sehingga tingkah laku yang dilakukan manusia selalu menampakkan dan menghasilkan tindakan-tindakan yang bersifat positif, konstruktif serta memberikan manfaat kepada kehidupan manusia maupun makhluk lainnya. Oleh karena itu penguasaan, pengendalian dan pengarahan emosi secara positif harus ditanamkan kepada anak-anak sejak usia dini.

Tanggung jawab orang tua terhadap anak dalam mengembangkan kemampuan untuk menguasai atau mengendalikan dan mengarahkan emosi menuju hal-hal yang positif perlu diwujudkan dalam bentuk komunikasi interaktif dengan menampilkan sikap kasih sayang, cinta, penghargaan, penghormatan terhadap perbuatan-perbuatan yang bersifat positif serta memberikan contoh atau suri tauladan perbuatan-perbuatan baik sesuai dengan moral, etika, keyakinan dan kaedah pergaulan yang diterima secara umum oleh masyarakat.

\section{DAFTAR PUSTAKA}

Abdullah Nashih Ulwan, Pendidikan Anak Dalam Islam, Terjemahan, Jamaluddin Miri (Jakarta: Pustaka Amani, 2007).

Abdullah Nashih Ulwan, Tarbiyatu Aulad Pendidikan Anak Dalam Islam, (Jakarta: Khatulistiwa Press, 2013).

Abu Amr Ahmad Sulaiman, Metode Pendidikan Anak Muslim Usia Prasekolah, Terjemahan, Abmad Amin Sjïhab Muraja'ah, dan M.Yusuf Harun, (Jakarta: Darul Haq, 2000).

Carole Wade, dkk, Psikologi,(Jakarta: Erlangga, 2014).

Dimitri Mahayana, Quantum Quotitent Kecerdasan Quantum, (Bandung: Nuansa, 2008).

Eilzabet B. Hurlock, Psikologi Perkembangan: Suatu Pendekatan Sepanjang rentang Kebidupan, (Jakarta: Erlangga, 1990). 2002).

Hasan Alwi, dkk, Kamus Besar Bahasa Indonesia,(Jakarta: Balai Pustaka,

Jalaludin, Psikologi Agama, (Jakarta: PT Raja Grafindo Persada, 2004). http//www.bppnfi-reg4.net/index.php/perkembangan-emosi-anak.html, (diakses, 7

Oktober 2012). 
Ilman Saputra dan Alzena Maskouri, Membangun Sosial Emosi Anak di Usia 4-6 tahun,(Jakarta: Dirjen PAUDNI, 2011).

John W. Santrock, Life-Spain Development, Perkembangan Masa Hidup, Diterjemahkan oleh Juda Damanik, Achmad Chusairi, Jakarta:Erlangga, 2002).

Janice J.Beaty, Observasi Perkembangan Anak Usia Dini, Jakarta: Kencana Pranadamedia, 2013).

M.Darwis Hude, Emosi: penjelajahan Religio-Psikologis tentang emosi manusia dalam Al-Quran, (Jakarta: Erlangga, 2006).

Novan Ardy Wiyani, Psikologi Perkembangan Anak Usia Dini, Panduan Orang tua dan Pendidik PAUD dalam Memahami serta Mendidik Anak Usia Dini,(Yogyakarta: Gava Media, 2014).

Novita Tandry, Mengenal Tahap Kembang Anak dan Masalabnya, Jakarta: Libri, 2011).

Tim Pustaka Phonix, Kamus Besar Bahasa Indonesia, Edisi baru, (Jakarta: PT Media Pustaka Phonix, 2010).

Teresa M.Mc.Devitt, Jeans Ellis Ormrod, Child Development and Education,(Upper Saddle River New Jersey Colombo Ohio: Merril Prentice Hall, 2002). 